\title{
Norsk bistand til legeutdanning i Malawi
}

\author{
Norad og den norske ambassaden i Malawi har i mange år støttet utdanningen av malawiske leger \\ ved å bygge opp et eget medisinsk fakultet i landet.
}

\begin{abstract}
Johanne Sundby
johanne.sundby@medisin.uio.no

Institutt for helse og samfunn

Universitetet i Oslo
\end{abstract}

\section{Robin Broadhead}

The College of Medicine

University of Malawi

I over ti år har Norge vært en avgjørende bidragsyter til et medisinsk fakultet (The College of Medicine) ved Universitetet i Malawi. Dette er det eneste medisinske fakultetet i Malawi og betjener en befolkning på 14 millioner. Norge har til sammenlikning fire medisinske fakulteter og om lag fem millioner innbyggere. Den norske staten har gitt hjelp med det mål å bygge opp et bærekraftig fakultet. Denne politikken har båret frukter. Fakultetet er blitt en akademisk institusjon med et godt omdømme både nasjonalt og internasjonalt.

\section{Historisk ramme}

Medisinske fakulteter er sjelden populære blant donatorer og politikere - de er for dyre å opprette og å drive. Da Malawi ble en uavhengig stat i 1964, fantes det ingen medisinske fakulteter i landet. Landet oppsto da føderasjonen mellom NordRhodesia (nå: Zambia), Sør- Rhodesia (nå: Zimbabwe) og Nyasaland (nå: Malawi) ble oppløst. Medisinske fakulteter i Lusaka (Zambia) og Harare (Zimbabwe) hadde tidligere forsynt Malawi med leger. Etter at føderasjonen ble oppløst ble det enda vans-

\section{«Den norske staten}

\section{har gitt hjelp med det mål å bygge opp et bærekraftig fakultet»}

keligere for malawiske studenter å få studieplass i disse nabolandene. Derfor måtte Malawi sende studenter til Europa og USA med stipend fra sponsorer. Dette var svært dyrt og ikke veldig effektivt, fordi legene ofte ikke ville komme tilbake. Det er lett å skjønne ? studentene var gjerne rundt 20 år da de forlot landet, de møtte sine fremtidige partnere, ble gift og stiftet familie der de studerte. Dessuten kunne de få jobb i et mer privilegert samfunn med færre politiske og økonomiske restriksjoner (1).

Derfor bestemte Malawi seg for å opprette en egen legeutdanning i 1986. Dette ble gjort etter anbefalinger fra en komité The Tripartite Commission, som besto av Storbritannia, Vest-Tyskland og Malawi. I 1986 lovet Storbritannia å ta imot 25 studenter per år i fire år for preklinisk og basal klinisk utdanning - med økonomisk støtte fra The Tripartite Commission. Malawi forpliktet seg til å etablere klinisk utdanning for studiets siste semestre. De første medisinstudentene kom tilbake til Malawi i september 1991 og var ferdig utdannet fra Universitetet i Malawi i juli 1992.

\section{Avgjørende bidrag}

Helt fra begynnelsen av har det medisinske fakultetet i Malawi vært helt avhengig av støtte fra utenlandske donatorer. Storbritannia og Vest-Tyskland var de første til å forplikte seg til å yte økonomisk støtte. Verdens helseorganisasjon (WHO) sa seg villig til å bidra for å lønne utenlandske spesialister som ble rekruttert for å starte opp legeutdanningen i landet. University of Flinders i Australia og University of Cape Town i Sør-Afrika sa seg også villige til å ta inn et visst antall unge studenter for preklinisk opplæring. Disse studentene kom tilbake for å gjennomføre kliniske semestre i 1994-95. Nederland har støttet helsevesenet i Malawi siden 1960-årene, først og fremst med å sende spesialister.

Det er ingen tvil om at denne støtten har vært avgjørende for å etablere et eget medisinsk fakultet. Imidlertid har skifte av regjeringer i giverlandene ført til endringer i støtten. Vest-Tyskland trakk tilbake sin støtte allerede før etableringen av legeutdanningen i Malawi. Denne avgjørelsen ble gjort etter at en malawisk nevrokirurg, som hadde fått sin grunnutdanning i Vest-Tyskland, ble fengslet uten rettssak eller andre formaliteter da han kom tilbake til Malawi - angivelig fordi han hadde kritisert styresmaktene der.

I 1994 trakk Storbritannia og Australia

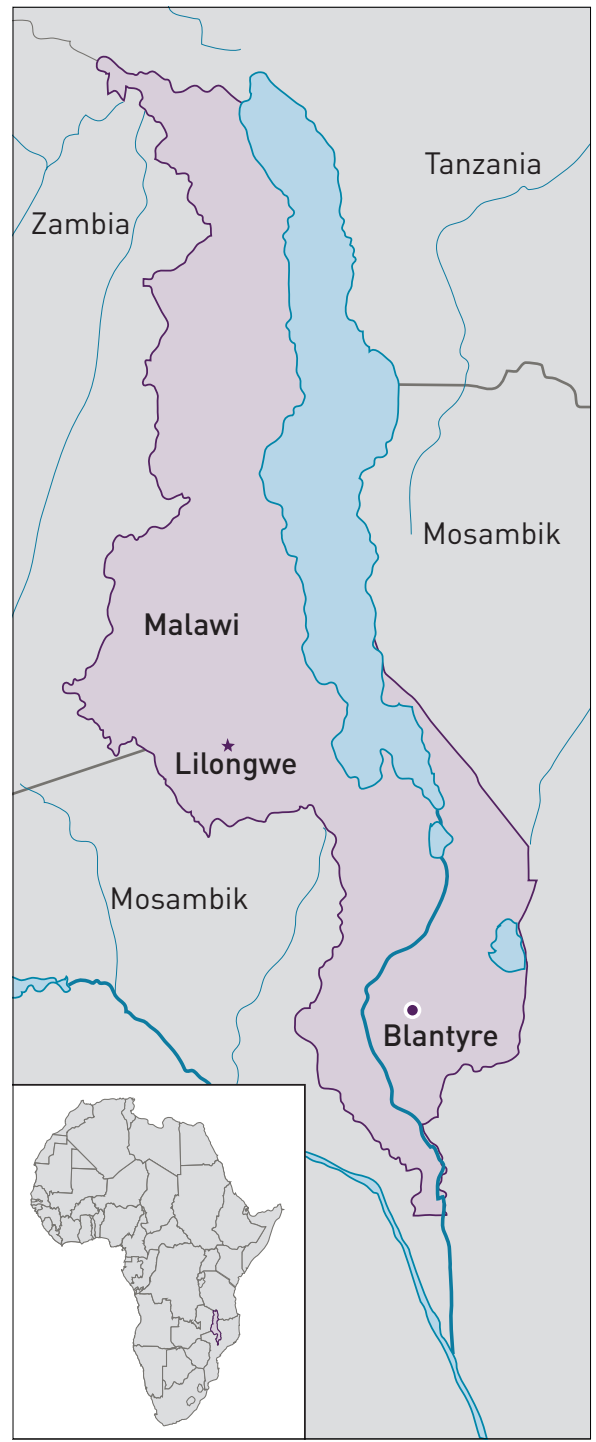

tilbake sin støtte. Dette ble begrunnet med et ønske om en politisk endring. Istedenfor å støtte faglig assistanse direkte skulle bistand kanaliseres gjennom enkeltprosjekter. Søkelyset var nå rettet mot primærhelsetjenesten - ikke sykehusmedisin og akademisk opplæring. Man mente at det ville være langt bedre for å løse de enorme helseutfordringene i land som Malawi. Resultatet ble at det ble vanskelig å utvide rammene for legeutdanningen i Malawi. I perioden 1992-2000 ble det utdannet færre enn 20 leger per år. 


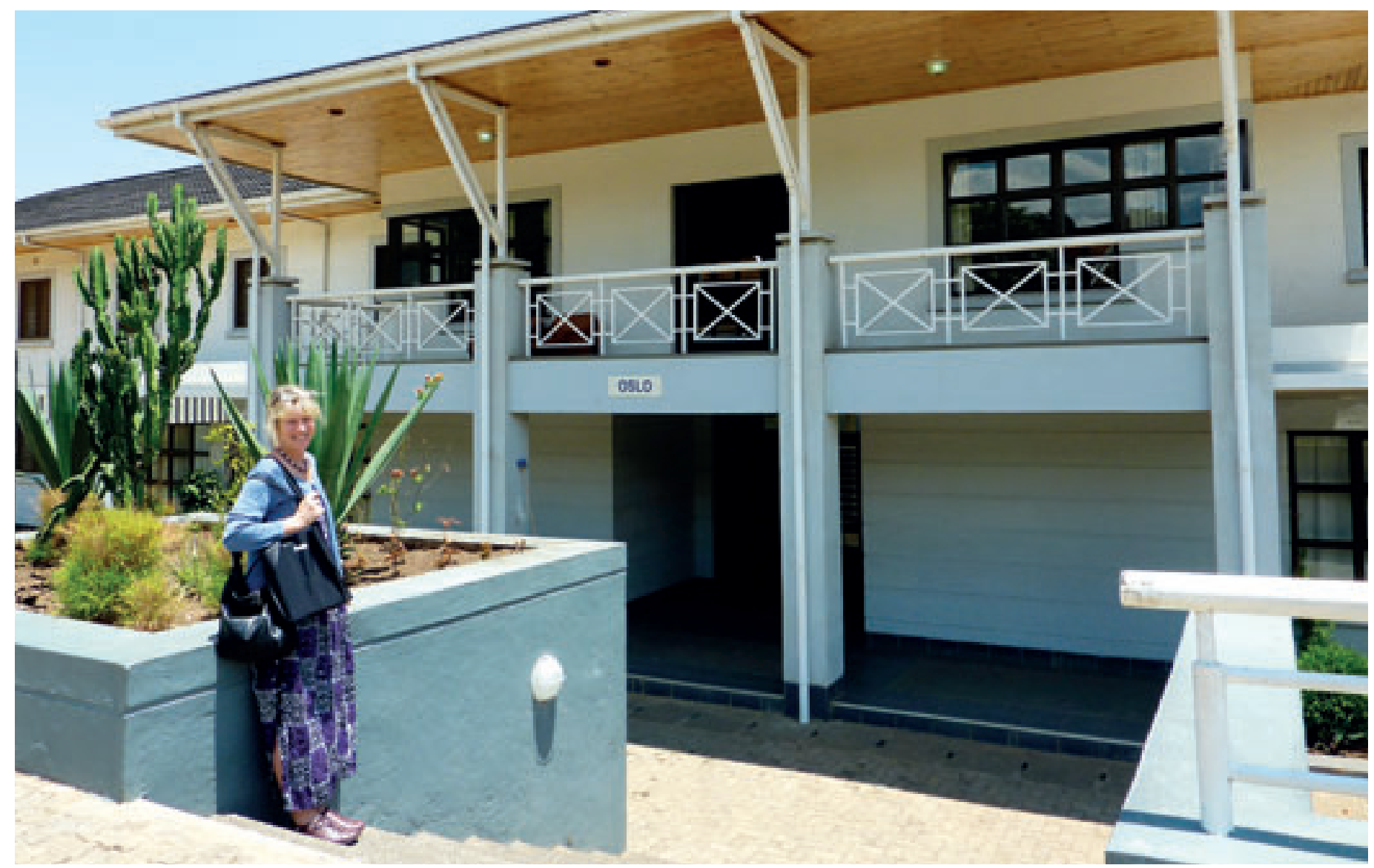

Norge har gitt økonomisk støtte til etableringen av en egen legeutdanning i Malawi. Her er førsteforfatter Johanne Sundby utenfor en av fakultetsbygningene, som har fått navnet Oslo. Foto Marilyn Lauglo

\section{Norsk støtte}

Norge etablerte en ambassade i Malawi i 1999 og har senere støttet det medisinske fakultetet i samarbeid med Sverige. Støtten har bidratt til at man har kunnet øke kapasiteten på medisinstudiet og andre helseutdanninger.

I den første fasen av dette samarbeidet, i 2000-03, var målet å bedre læremiljøet på Queen Elizabeth Central Hospital, som er et stort universitetssykehus i byen Blantyre. Dessuten ønsket man å bli mindre avhengig av lærere fra andre land, som ofte arbeidet på dyre korttidskontrakter. Dette lyktes man med.

Senere ble hovedmålet å øke inntaket av medisinstudenter til minst 60 per år, og opp til dagens nivå, som er 90 nye studenter per år. I denne fasen finansierte Norge og Sverige byggingen av fire bygninger, blant annet studentboliger, kafeteria, nytt bibliotek og et idrettsanlegg. Slike tiltak for å støtte studentene var viktige - ettersom fakultetet ligger geografisk separat fra resten av universitetet. I 2007 startet man egne bachelorutdanninger i farmasi og biologisk laboratorieteknologi.

I en tredje fase med finansiell støtte, i perioden 2006-09, var hovedmålet å støtte doktorgradsstudier. Malawiske kandidater fikk stipend fra Norge for å ta videre- og etterutdanning i ulike spesialiteter i Sør-
Afrika. Hensikten var å forsyne Malawi med sine egne spesialister og på den måten minske avhengigheten av utenlandske eksperter. Politikken har vært vellykket. Fakultetet i Malawi har utviklet egne mastergrader i de fleste store kliniske disiplinene (2). Norge vil også støtte byggingen av et eget institutt for slik videreutdanning, der man i stor grad vil ta i bruk moderne informasjonsteknologi i undervisningen.

\section{«Medisinske fakulteter}

\section{er sjelden populære}

\section{blant donatorer}

\section{og politikere»}

Disse fremskrittene har ført til en ny, fjerde fase fra 2010. Det er innført to nye studieprogrammer - en fireårig utdanning i fysioterapi, med støtte fra blant annet Universitetet i Tromsø, og en bachelorutdanning i helseledelse. Norge har også bidratt med midler til forskning i samarbeid med norske forskningsinstitusjoner.

Norge har fulgt to gode prinsipper i sin støtte til det medisinske fakultetet ved Universitetet i Malawi: å ha et langtidspers- pektiv for sin støtte og å la mottakerlandet selv gjøre sine egne prioriteringer. Denne politikken - at man skal jobbe med stor grad av fleksibilitet og i harmoni med institusjonens egne mål - gir grobunn for en nær ideell modell for partnerskap.

\section{Johanne Sundby (f. 1951)}

er professor i samfunnsmedisin ved Det medisinske fakultet, Institutt for helse og samfunn, Universitetet i Oslo.

Oppgitte interessekonflikter: Har et NUFUstipend (Nasjonalt program for utvikling, forskning og utdanning) for forskningssamarbeid med det medisinske fakultetet i Malawi.

\section{Robin Broadhead (f. 1943)}

er pediater og tidligere dekanus ved The College of Medicine, University of Malawi Ingen oppgitte interessekonflikter.

\section{Litteratur}

1. Muula AS. Nationality and country of training of medical doctors in Malawi. Afr Health Sci 2006; 6: $118-9$.

2. Zijlstra EE, Broadhead RL. The College of Medicine in the Republic of Malawi: towards sustainable staff development. Hum Resour Health 2007; 13: 5-10.

Mottatt 30.6. 2011, første revisjon innsendt 29.8. 2011, godkjent 1.9. 2011. Medisinsk redaktør Petter Gjersvik. 